\title{
Implication of Global Outreach Program Organizing in Student Leadership, Entrepreneurship and Academic Performance: Kembara Ilmu Perdana Palembang 2019 Case Study
}

\author{
Mohd Murtadha Mohamad ${ }^{1 *}$, Mohd Fadthul Ikmal Misnal ${ }^{2}$, Md Yani Kasiren ${ }^{3}$, Md \\ Hafiz Selamat ${ }^{4}$, Mohammad Firdaus Wahyudin ${ }^{5}$, Norahim Ibrahim ${ }^{6}$ \\ ${ }^{1}$ School of Computing, Faculty of Engineering, Universiti Teknologi Malaysia, 81310 Johor Bahru. \\ ${ }^{2}$ School of Mechanical Engineering, Faculty of Engineering, Universiti Teknologi Malaysia, 81310 Johor Bahru. \\ ${ }^{3}$ Centre for Community and Industry Network, Office of Deputy Vice Chancellor (Research \& Innovation), Universiti \\ Teknologi Malaysia, 81310 Johor Bahru. \\ ${ }^{4}$ Azman Hashim International Business School, Universiti Teknologi Malaysia, 81310 Johor Bahru. \\ ${ }^{5}$ Security Division, Office of Registrar, Universiti Teknologi Malaysia, 81310 Johor Bahru. \\ ${ }^{6}$ Department of Bioscience, Faculty of Science, Universiti Teknologi Malaysia, 81310 Johor Bahru. \\ *Corresponding author. Email: murtadha@utm.my
}

\begin{abstract}
Global Outreach Program (GOP) is one of the UTM initiative under Transformative Campus Experience which acts as comprehensive and global learning experience for UTM students. Despite being the added value to produce holistic student in terms of leadership and entrepreneurship, concern also had increased whether GOP involvement will influence the academic performance of the students. Therefore, the effect of GOP organizing towards the leadership and entrepreneurship skills as well as academic performance were studied. In this study, descriptive statistics is being utilized as the main tool of data analysis, involving 17 respondents of organizing committee. The findings shown that the student involvement in GOP had significantly improved their leadership skill (in terms of communication, problem-solving and teamwork), entrepreneurship skill as well as maintained their excellence academic performance.
\end{abstract}

Keywords: Global Outreach Program; Leadership; Entrepreneurship; Academic Performance

\section{INTRODUCTION}

In line with Malaysia Education Development Plan (Higher Education) 2015-2025, Universiti Teknologi Malaysia (UTM) provides widened access policy for student to experience Transformative Campus Experience, which included as one of key focus area (KFA) in UTM Global Plan Phase III (2018-2020) [1]. This is an opportunity for UTM student to involve in comprehensive learning experience in terms of co-curricular activities participation and at the same time improve their soft skills. Therefore, towards producing human capital with firstclass attitude and mentality, possess holistic entrepreneurial skills, as well as brave enough to explore the global culture, UTM through UTM International Office offering five categories of mobility programs such as Student Exchange Program, Research Internship Abroad, Global Outreach Program (GOP), International Invitation Program (IIP) and Summer School Abroad [2].
Initiative had been taken by Student Committee of Kolej Perdana (Jawatankuasa Kolej Mahasiswa Kolej Perdana, JKM KP) UTM in organizing Global Outreach Program (GOP): Kembara Ilmu Perdana Palembang 2019. This program become the knowledge and cultural exchange platform between UTM students (all participants from JKM KP) with Sekolah Tinggi Ilmu Ekonomi (STIE) Lembah Dempo and Universitas Sriwijaya, Palembang. At the same time, UTM with the marketing expertise from Azman Hashim International Business School (AHIBS) offered consultation and idea brainstorming in order to enhance the promotion and publicity of eco-tourism in Lembah Dempo, Pagar Alam.

Since GOP is regarded as among high impact activity organized by students, it is interesting to study its implication towards leadership and entrepreneurship attributes of UTM students as well as their academic performance. Therefore, this paper will study on the effect of GOP organizing towards the leadership and entrepreneurship skills as well as academic performance, 
especially for the organizing committee of Kembara Ilmu Perdana Palembang 2019.

\section{LITERATURE REVIEW}

In line with the millennium era of education transformation, the new perspective towards the idea of student leadership became the highlight of education policy maker [3, 4]. According to Guthrie and Jenkins (2018), leadership can be defined as "changes in knowledge, skills, behaviour, attitudes, and values resulting from educational experiences, both co-curricular and curricular in nature, associated with the activity of leadership" [5]. Various leadership programs and modules were developed in order for the students to improve their leadership skill [6]. However, several scholars have argued that leadership development should became a priority to build up the strong leadership characteristics, especially at young age [7-9].

It can be summarized that the leadership learning consists of six main elements which are knowledge, development, training, observation, engagement as well as metacognition [5]. Leadership knowledge is the fluid process interaction between leader and followers. Leadership development is characterized by identity, values and motivation in leadership activity. Meanwhile, leadership training indicated by efficiency in delivering specific task. Evaluation on effective and ineffective style of leadership is the process of leadership observation. Besides, leadership engagement involves experience, interaction and interpersonal components of leadership learning process whereas the understanding about leadership process is categorized under leadership metacognition.

Apart from leadership learning process, entrepreneurship education is another crucial skill for students in this era [10]. Globally, in line with demanding focus on practical approach learning [11], as well as increasing demands in job and wealth creation [12], the entrepreneurship education is no longer a choice. Through entrepreneurship education, students are trained to lead, communicate as well as apply the various business strategies in order to build up their character of entrepreneur. In fact, it is a right platform to nurture the job creator mindset instead of conventional job seeker mentality [13].

As emphasis are given to soft-skills training and experience, concern also had increased whether too much extra co-curricular activities involvement will influence the academic performance of the students. Negative impact such as stress and depression might occurred due to student's inability to balance their academic and extra cocurricular workloads [14]. However, there is an evidence where the extra co-curricular involvement led to the professional development opportunities for students, which supported deep learning, resulted in excellence academic performance [15].
Therefore, it is interesting to study and evaluate the impacts of student involvement in extra co-curricular (which in this case is GOP) towards their leadership and entrepreneurship skills as well as current academic performance.

\section{METHODOLOGY}

In this study, descriptive statistics which quantitatively described or summarized the features of data collection is being utilized as the main tool of data analysis. To achieve and fulfil the research objectives, questionnaire was distributed to targeted respondents through Google Form aps. Targeted respondents were 17 organizing committee of Kembara Ilmu Perdana Palembang 2019, who were also the member of Student Committee of Kolej Perdana (Jawatankuasa Kolej Mahasiswa Kolej Perdana, JKM KP) UTM

The distributed questionnaire consists of 14 questions including four questions about respondent demographic, one question about current cumulative grade pointer average (CGPA) range, two question about communication skill attribute, two question about problem solving skill attribute, two question about teamwork spirit attribute as well as three questions about entrepreneurship skill. The analysis of data was presented in form of descriptive statistics of frequency and percentage.

Table 1 Questions descriptions in distributed surveys.

\begin{tabular}{|c|c|c|c|}
\hline \multicolumn{4}{|c|}{ Demographic Section } \\
\hline No. & Question & No. & Question \\
\hline 1 & Gender & 3 & Year of Study \\
\hline 2 & Age & 4 & Faculty \\
\hline \multicolumn{4}{|c|}{ Academic Performance } \\
\hline No. & \multicolumn{3}{|c|}{ Question Description } \\
\hline 5 & \multicolumn{3}{|c|}{ Current CGPA } \\
\hline \multicolumn{4}{|c|}{ Leadership Attribute (Communication Skill) } \\
\hline No. & \multicolumn{3}{|c|}{ Question Description } \\
\hline 6 & \multicolumn{3}{|c|}{$\begin{array}{l}\text { Communication skill improvement in terms of } \\
\text { delivering message/response/feedback among } \\
\text { organizing committee. }\end{array}$} \\
\hline 7 & \multicolumn{3}{|c|}{$\begin{array}{l}\text { Communication skill improvement in terms of } \\
\text { confidence in giving instructions to other } \\
\text { organizing committee. }\end{array}$} \\
\hline \multicolumn{4}{|c|}{ Leadership Attribute (Problem Solving Skill) } \\
\hline No. & \multicolumn{3}{|c|}{ Question Description } \\
\hline 8 & \multicolumn{3}{|c|}{$\begin{array}{l}\text { Problem solving skill improvement by identify } \\
\text { the root cause of the problem. }\end{array}$} \\
\hline 9 & \multicolumn{3}{|c|}{$\begin{array}{l}\text { Problem solving skill improvement by ability to } \\
\text { consider the upcoming implications of solution. }\end{array}$} \\
\hline \multicolumn{4}{|c|}{ Leadership Attribute (Teamwork Spirit) } \\
\hline No. & \multicolumn{3}{|c|}{ Question Description } \\
\hline 10 & \multicolumn{3}{|c|}{$\begin{array}{l}\text { Teamwork spirit improvement by ability to } \\
\text { adapt and interact with other organizing } \\
\text { committee. }\end{array}$} \\
\hline
\end{tabular}




\begin{tabular}{|c|l|}
\hline 11 & $\begin{array}{l}\text { Teamwork spirit improvement by having } \\
\text { collective decision instead of individual } \\
\text { decision. }\end{array}$ \\
\hline Entrepreneurship Attribute \\
\hline No. & \multicolumn{1}{|c|}{ Question Description } \\
\hline 12 & Preferred income generation strategies. \\
\hline 13 & Time allocation to generate additional income. \\
\hline 14 & $\begin{array}{l}\text { Improvement of entrepreneurship and } \\
\text { negotiation skills. }\end{array}$ \\
\hline
\end{tabular}

On the other hand, Table 1 shows the questions descriptions in distributed surveys to all 17 targeted respondents. It is noted that the leadership attribute was divided into three components; communication skill, problem solving skill as well as teamwork spirit. From literature review section, leadership learning elements consists of knowledge, development, training, observation, engagement as well as metacognition. In this study, communication skill is part of leadership engagement as well as leadership metacognition. Meanwhile, problem solving skill is part of leadership training, which focused on efficiency in delivering specific task (in this case, ability to solve the existing problem). Third component tested were teamwork spirit, which is part of leadership engagement between leader and followers. In general, all components investigated in this study (communication skill, problem solving skill and teamwork spirit) were related with leadership elements of training, engagement as well as leadership metacognition.

\section{RESULTS AND FINDINGS}

In this section, impacts of student involvement in GOP (Kembara Ilmu Perdana Palembang 2019) were discussed in terms of their leadership attribute, entrepreneurship attribute as well as their academic performances.

\subsection{Leadership Attribute}

Leadership attribute analysed and evaluated in this study consists of three different elements which are communication skill, problem solving skill and teamwork spirit. Figure 1 showed the findings on communication skill improvement in terms of delivering message as well as confidence in giving instructions among the organizing committee. From the findings in Figure 1, it is apparent that $100 \%$ respondents (all 17 respondents) agreed that their involvement in GOP significantly improved their communication skill in terms of delivering message among the organizing committee.

Besides, 94\% respondents (16 respondents) agreed that their involvement in GOP significantly improved their communication skill in terms of giving instruction to others, based on Figure 2. Communication skill is one of the crucial elements which contributed to quality leadership attribute under the aspect of leadership engagement and leadership metacognition [5].

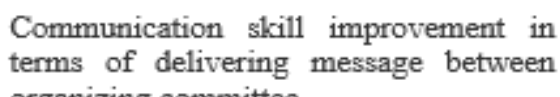
organizing committee

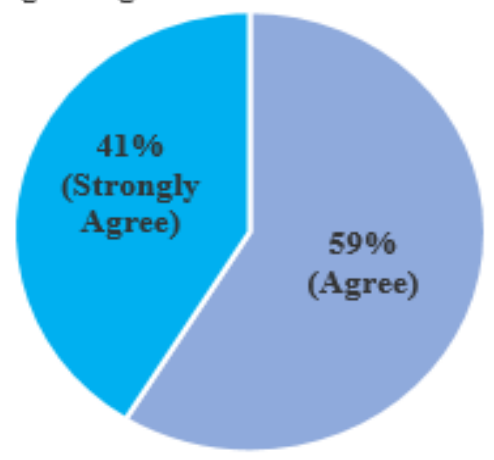

Figure 1 Finding in communication skill improvement in terms of delivering message between organizing committee.
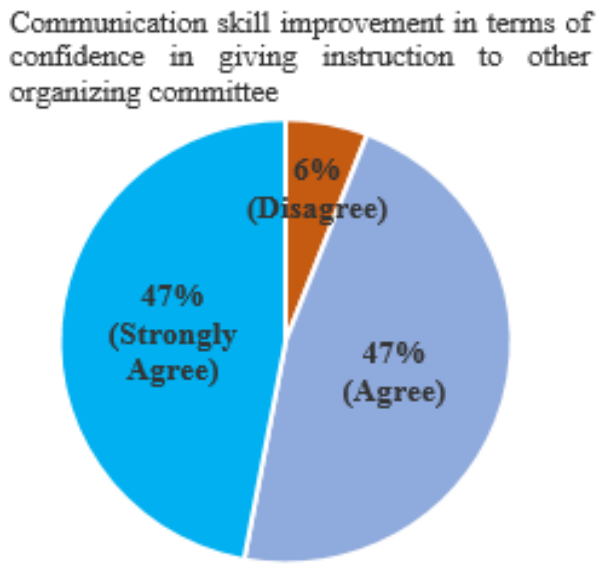

Figure 2 Finding in communication skill improvement in terms of confidence in giving instruction to other organizing committee.

Meanwhile, Figure 3 illustrated the problem-solving skill improvement in terms of ability to determine the root cause of problem as well as ability to consider the upcoming implications of the given solution. From Figure 3 , it can be seen that $94 \%$ respondents (16 respondents) agreed that their involvement in GOP significantly improved their problem-solving skill by the ability to identify the root cause of problem. Whereas, $100 \%$ respondents (17 respondents) agreed that they were able to consider the upcoming implications of the given solution, based on Figure 4. Problem solving-skill is very important in order to produce our future leaders who can analyse and further evaluate the implication for every decision making. GOP is among the appropriate platform for the students to experience the real situation of problem, as we believed that the students can learn from their mistake in decision making as part of leadership learning process [5]. 
Problem solving skill improvement by ability to identify the root cause of problem

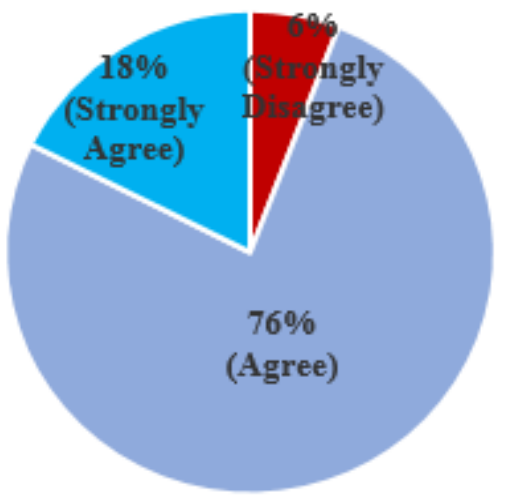

Figure 3 Finding in problem solving skill improvement in terms of ability to identify the root cause of problem.
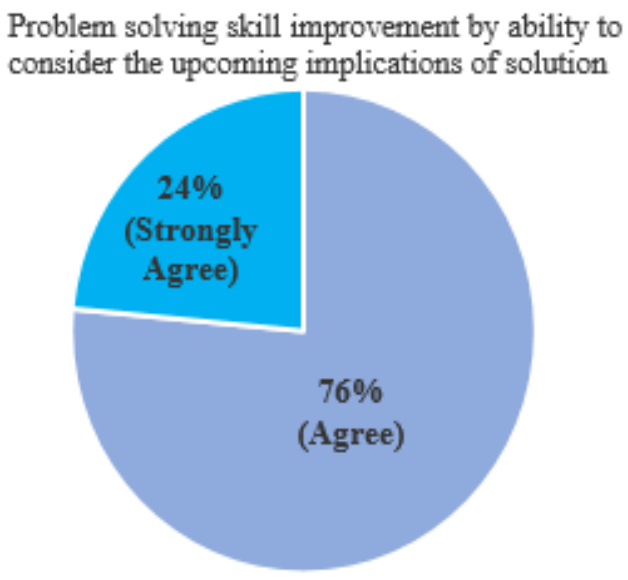

Figure 4 Finding in problem solving skill improvement in terms of ability to consider the upcoming implications of solution.

Apart from communication and problem-solving skills evaluation, teamwork spirit is also being evaluated. Teamwork spirit improvement in terms of ability to adapt and interact with other organizing committee as well as having collective decision making instead of individual decision making are shown in Figure 5 and Figure 6. From the findings in Figure 5 and Figure 6 , it seems that majority of the respondents, $94 \%$ (16 respondents) agreed that their involvement had significantly enhanced their teamwork spirit, by able to interact with each other as well as having collective decision making. The evidence indicated that GOP is the right platform for students to have a strong teamwork bonding until they are being loyal to each other, eventually led to effective leadership learning in the aspects of leadership development, observation, engagement as well as metacognition [5].
Teamwork spirit improvement by ability to adapt and interact with other organizing committee

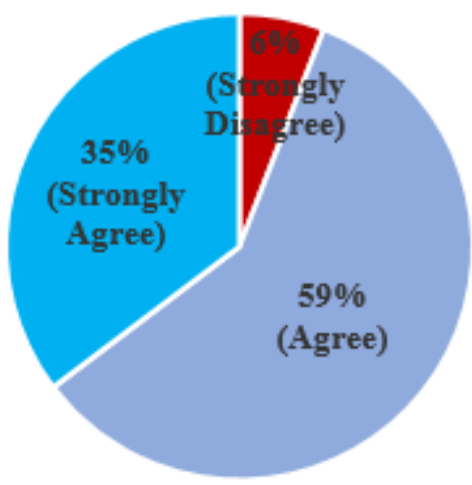

Figure 5 Finding in teamwork spirit improvement by ability to adapt and interact with other organizing committee.

\section{Teamwork spirit improvement by having the collective decision making instead of individual decision making}

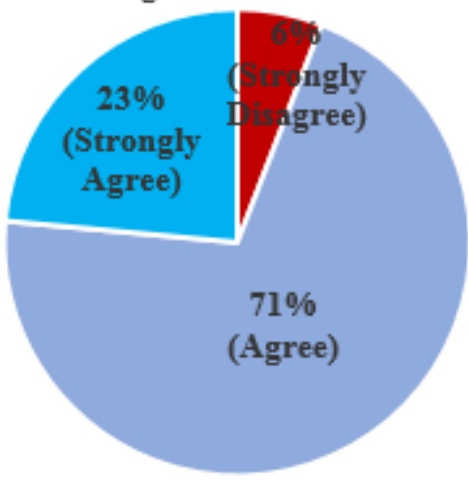

Figure 6 Finding in teamwork spirit improvement by having the collective decision making instead of individual decision making.

In general, involvement in GOP had given positive implication in terms of leadership attribute especially in improvement of communication skill (clear message delivering and confidence in giving instruction), problem solving skill (identify the root cause of problem and consider upcoming implications of solution) as well as teamwork spirit (ability to adapt and interact, also having collective decision making instead of individual decision making). Those skills improvement directly related with leadership elements of training (problem solving skill), engagement (communication skill, teamwork spirit) as well as leadership metacognition (communication skill) [5]. 


\subsection{Entrepreneurship Attribute}

In this finding, the entrepreneurship attribute was analysed and evaluated through the identification of entrepreneurship and negotiation skills enhancement, income generation preferred strategies as well as allocated duration preferred to generate income. Figure 7 shows the entrepreneurship and negotiation skills enhancement through GOP involvement. Majority of the respondents, 94\% (16 respondents) agreed that their involvement in GOP significantly enhanced their entrepreneurship and negotiation skills. In order to support the GOP expenses, the organizing committee were required to generate income through entrepreneurship. For the case of Kembara Ilmu Perdana Palembang 2019, the organizing committee was able to achieve the total sales of RM 2, 481 with net profit of RM 858 from entrepreneurship activity of selling foods and drinks during 62nd UTM Convocation Festival. The corresponding net profit amount successfully covered $7 \%$ from overall expenses of RM 11, 465. This is a real case evidence where entrepreneurship significantly contributed to cover the expenses. Throughout the entrepreneurship activity, students were required to smartly deal and negotiate with food suppliers, eventually trained them to lead, communicate as well as apply the various business strategies in order to build up their character of entrepreneur [13].

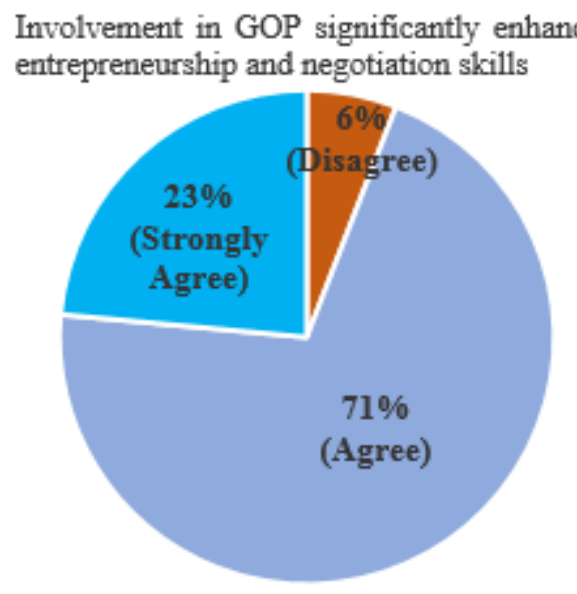

Figure 7 Finding in entrepreneurship and negotiation skills enhancement through GOP involvement.

Meanwhile, preferred income generation strategies and allocated duration to generate income were shown in Figure 8 and Figure 9 respectively. Majority of the respondents, 59\% (10 respondents) preferred all listed strategies for the sake of income generation for GOP. Significant number of respondents preferred sponsorship and corporate collaboration (17\%, 3 respondents) as well as entrepreneurship (12\%, 2 respondents). It is true because the income generation of GOP cannot depend with only one single strategy. In fact, all listed strategies had been carried out to generate the additional income. In our case, apart from entrepreneurship, strategic cost cut seems significantly contributed to reduce the expected expenses by RM 1, 474 (reduction of approximately 12\%).

In terms of allocated duration preferred to generate income, $47 \%$ respondents (8 respondents) preferred 6 months duration, 35\% (6 respondents) preferred 1-year duration whereas another $18 \%$ (3 respondents) said it depends on situation. This finding indicated that majority of students believed and had confidence to generate income for GOP within 6 months to 1 -year duration. Therefore, the timeline or milestone created for income generation should be within that corresponding duration.

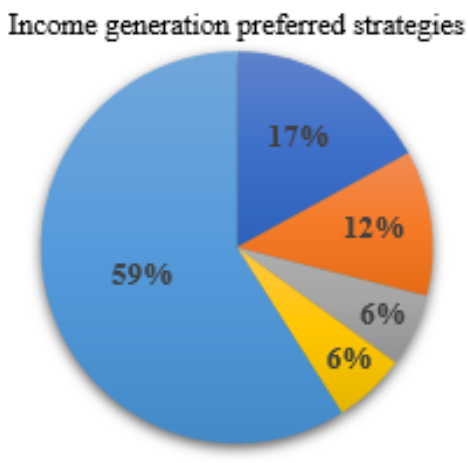

- Sponsorship \& corporate collaboration

घntrepreneurship

- Strategic cost cut (i.e flight ticket \& accomodation discount)

$\square$ Self-sponsored (including family financial support)

- All listed strategies

Figure 8 Finding in income generation preferred strategies.

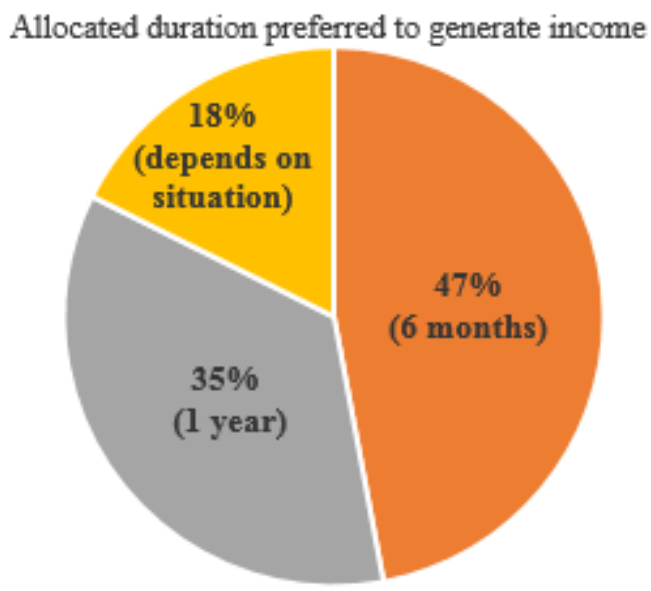

Figure 9 Finding in allocated duration preferred to generate income. 


\subsection{Academic Performance}

As the leadership and entrepreneurship skills are being analysed and evaluated, we cannot deny that academic performance still plays a major role to indicate the product of excellent student. Figure 10 showed the cumulative grade pointer average (CGPA) achieved by all 17 GOP organizing committee of Kembara Ilmu Perdana Palembang 2019. 88\% of respondents (15 respondents) had achieved CGPA above 3.00 while another $12 \%(2$ respondents) had achieved CGPA below 3.00. In fact, there were $41 \%$ respondents (7 respondents) who had successfully maintained the CGPA above 3.50. This is real case evidence which showed that the involvement in GOP did not negatively influenced the academic performance of the students. In fact, GOP involvement led to the professional development opportunities for students, which supported deep learning, eventually resulted in excellence academic performance [15].

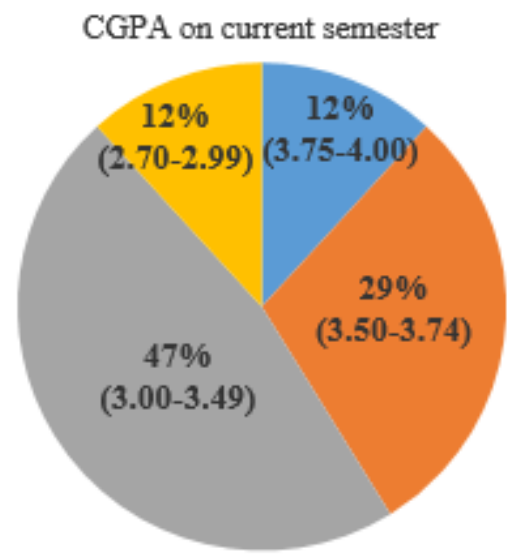

Figure 10 CGPA on current semester recorded by all respondents.

\section{CONCLUSION}

In this study, the effect of GOP organizing towards the leadership and entrepreneurship skills as well as academic performance, especially for the organizing committee of Kembara Ilmu Perdana Palembang 2019 were analysed and evaluated. This study has shown that the student involvement in GOP had showed positive implications on their leadership skills (in terms of communication, problem-solving and teamwork), entrepreneurship skill as well as maintained their excellence academic performance.

\section{ACKNOWLEDGMENT}

Highest gratitude and thanks to Department of Deputy Vice Chancellor (Student Affairs) UTM, Office of UTM International, Azman Hashim International Business School (AHIBS), Principal of Kolej Perdana, Council of
Fellows Kolej Perdana as well as Jawatankuasa Kolej Mahasiswa (JKM) Kolej Perdana session 2018/2019.

\section{REFERENCES}

[1] Shahrin Mohammad, Masputeriah Hamzah, Narina A. Samah, Mohd Bakri Bakar, Lokman Mohd Tahir, Sharifah Osman, Jamilah Ahmad \& Abdul Halim Abdullah (2018). UTM Global Plan 2012-2020 Phase III: 2018-2020 \& enVision UTM 2025. Johor Bahru: Strategy Management Office, Office of the Vice Chancellor, Universiti Teknologi Malaysia.

[2] Outbound Mobility Programs. (n.d.). Retrieved from https://www.utm.my/international/outbound-mobilityprograms/

[3] Black, R., Walsh, L., Magee, J., Hutchins, L., Berman, N., and Groundwater-Smith, S. (2014). Student Leadership: A Review of Effective Practice. Canberra: ARACY.

[4] Adams, D. \& Velarde, J. (2018). Leadership and Management in Education: Role and Influence. In D. Adams (Ed.), Mastering Theories of Educational Leadership and Management. Kuala Lumpur: University of Malaya Press.

[5] Guthrie, K. L., \& Jenkins, D. M. (2018). The role of leadership educators: Transforming learning. Charlotte, NC: Information Age Publishing.

[6] Tan, M. H., \& Adams, D. (2018). Malaysian student leaders' perception of their leadership styles. International Journal of Innovation and Learning, 23(3), 368-382.

DOI: https://doi.org/10.1504/IJIL.2018.091094

[7] Adams, D., Kamarudin, F. \& Tan, M.H.J. (2018). Student Leadership: Development and Effectiveness. In D. Adams (Ed.), Mastering Theories of Educational Leadership and Management. Kuala Lumpur: University of Malaya Press.

[8] Villarreal, S., Montoya, J. A., Duncan, P., \& Gergen, E. (2018). Leadership styles predict career readiness in early college high-school students. Psychology in the Schools, 55(5), 476-489.

DOI: https://doi.org/10.1002/pits.22131

[9] Keselman, A., Ahmed, E. A., Williamson, D. C., Kelly, J. E., \& Dutcher, G. A. (2015). Harnessing health information to foster disadvantaged teens' community engagement, leadership skills, and career plans: A 
qualitative evaluation of the Teen Health Leadership Program. Journal of the Medical Library Association, 103(2), 82-86.

DOI: https://doi.org/ 10.3163/1536-5050.103.2.005

[10] Greene, P.G. and Rice, M.P. (2011), "The experience in the United States: a university perspective", in Butler, J.S. and Gibson, D.G. (Eds), Global Perspectives on Technology Transfer and Commercialization: Building Innovative Ecosystems, Edward Elgar, Cheltenham, pp. 364-381.

[11] Jones, P., Maas, G. and Pittaway, L. (2017), Entrepreneurship Education: New Perspectives on Entrepreneurship Education, Emerald Publishing, Bingley.

[12] Foss, L. and Gibson, D.V. (2015), The Entrepreneurial University: Context and Institutional Change, Routledge, Oxon.

[13] Zainudin, M., Hadi, C., \& Suhariadi, F. (2019). Student Entrepreneurial Intention Towards Entrepreneurship Course with Different Credit Loading Hours. International Journal of Entrepreneurship, 23(1), 1-20.

[14] Ford, K., Olotu, B., Thach, A., Roberts, R., \& Davis, P. (2014). Factors contributing to perceived stress among doctor of pharmacy (PharmD) students. College Student Journal, 48(2), 189-198.

[15] Fox, L. M., \& Sease, J. M. (2019). Impact of cocurricular involvement on academic success of pharmacy students. Currents in Pharmacy Teaching and Learning, 11(5), 461-468.

DOI:https://doi.org/https://doi.org/10.1016/j.cptl.2019.0 2.004 